\title{
Cytotoxicity Tests for Evaluating Medical Devices: An Alert for the Development of Biotechnology Health Products
}

\author{
M. N. P. Vidal ${ }^{1}$, J. M. Granjeiro ${ }^{2,3,4}$
}

${ }^{1}$ National Institute of Quality Control in Health of the Oswaldo Cruz Foundation (INCQS/FIOCRUZ), Manguinhos, Brasil; ${ }^{2}$ Fluminense Federal University, Post-Graduation Program in Biotechnology, Niterói, Brazil; ${ }^{3}$ Quality and Metrology of the National Institute of Metrology, Quality and Technology, Directory of Metrology Applied to Life Sciences, Rio de Janeiro, Brazil; ${ }^{4}$ The Brazilian Branch of Institute of Biomaterials, Tribocorrosion and Nanomedicine (IBTN), Rio de Janeiro, Brazil

Correspondence to: M. N. P. Vidal, mirian.vidal@incqs.fiocruz.br, vidalmn@gmail.com

Keywords: Biotechnology, Medical Devices, Biomaterials, Biocompatibility, Health Products, In Vitro Cytotoxicity Assay

Received: August 18, $2017 \quad$ Accepted: September 27, $2017 \quad$ Published: September 30, 2017

Copyright $\odot 2017$ by authors and Scientific Research Publishing Inc.

This work is licensed under the Creative Commons Attribution International License (CC BY 4.0).

http://creativecommons.org/licenses/by/4.0/

\section{(c) (i) Open Access}

\section{ABSTRACT}

The risks and damages related to the use of products, technologies and services of sanitary interest can be due to defects or manufacturing failures. Certain products already contain a certain degree of risk, which requires strict quality control in their production, distribution and use, as well as in the disposal of their waste in the environment. With continuous development in science and technology, medical devices must undergo intradermal irritation and testing for sensitization, cytotoxicity, and acute systemic toxicity. In health care, biotechnology aims to provide technology-based products or processes related to energy, food, and health, which are capable of stimulating new businesses, expanding exports, integrating the value chain and stimulating new demands for innovative products and processes, taking into account health policies. The present article was prepared by a bibliographical survey of the electronic databases PubMed, Lilacs, and Bireme. Cell culture testing can be successfully employed, as it is reproducible, rapid, sensitive, and financially accessible for performing in vitro toxicity testing. Thus, it has been possible to optimize the development phase of new products by decreasing animal use or even replacing them in certain tests. Some in vitro assays validated by the Organization for Economic Cooperation and Development in the area of health products have already replaced animal testing.

\section{INTRODUCTION}

Today, the world seems to be increasingly exposed to risks and hazards, particularly in relation to the 
production, distribution and use of health products, which can often create risks for the population [1].

Risks and harmful effects related to the use of health products, technologies, and services may be due to manufacturing defects or flaws, misdiagnoses, incorrect prescriptions or intentional illicit acts on the part of manufacturers, sellers or service providers. Certain products have a certain degree of inherent risk or hazard, making the strict monitoring of their production, distribution and use, as well as disposal as waste in the environment, essential. Considering the large-scale production and active distribution of goods in a globalized economy, defective products placed on the market may lead to health risks that affect a population to an extent that extends beyond a country's borders [1,2].

With the continuous development in science and technology, these devices should undergo testing for biocompatibility or cytotoxicity, sensitization, intradermal irritation and acute systemic, among others, before being used in a clinical environment, in order to ensure their safe and effective use in humans [3].

In recent years, the use of biotechnology has led to breakthroughs in the development of biomaterials and bioproducts for utilization as medical devices, such as devices developed to promote tissue repair and provide controlled release of drugs and biopharmaceuticals [4].

In the Brazilian healthcare system, biotechnology is used to stimulate the generation and control of technologies. The consequent national production can be used to promote the competitive position of the Brazilian bio-industry within the international biotechnology community, being capable of generating new businesses, expanding exports, integrating the value chain and stimulating new demands for innovative products and processes [5].

\section{CONCEPTS}

\subsection{Biotechnology}

According to the United Nations Food and Agriculture Organization definition, biotechnology can be applied to scientific and engineering principles for processing materials using biological agents and providing quality products or services [6].

The National Council for Scientific and Technological Development (CNPq-Brazil) has defined biotechnology as the use of cellular systems to obtain products and develop processes. Biotechnology is associated with the use of modern molecular and cell biology techniques [5].

The main objective of the Biotechnology Development Policy is "to promote and carry out actions to establish a suitable environment for the development of innovative products and biotechnological processes and to stimulate the increased efficiency of the national production structure, innovation capacity of Brazilian companies, absorption of technologies, generation of businesses, and expansion of exports" $[6,7]$.

Biotechnology enables the modification and development of methods for diagnosing diseases and the improvement of new treatment techniques, such as those producing bioproducts and smart bio-materials. For this purpose, industries require several years to develop and perform safety tests before a product can be made commercially available. Food, cosmetic, pharmaceutical, or biopharmaceutical products require registration with a regulatory agency in Brazil: the National Health Surveillance Agency (ANVISA).

ANVISA, besides offering information about effectiveness and safety, plays a role in the process of product registration. It is also in the interest of ANVISA to receive information about studies that will be conducted in Brazil involving medications and other products developed within the country $[8,9]$.

\subsection{Medical Devices}

Medical devices are health products intended for use in the human body for the prevention, control, diagnosis or treatment of a disease through means that cannot be reached by pharmacological, immunological, or metabolic medications. This is what distinguishes medical devices from medications, although both contribute to improving user's health and quality of life [10].

For legal purposes, medical devices are products that come under the regime of producer liability. 
However, they display a specific characteristic due to their function and the specific context in which they are used: they are products (materials or similar articles) designed for medical purposes (diagnosis, prevention, control, treatment, or alleviation of an illness or suffering) that cannot be attained through pharmacological, immunological or metabolic means [11].

A major innovation for Brazilian medical devices was the creation of the National Surveillance System for Medical Devices, which places additional obligations on manufacturers to report adverse effects. The purpose of the National Surveillance System for Medical Devices is to monitor devices after they have entered the market, to prevent injuries to patients, particularly recurrent injuries. Despite the various tests that medical devices are subjected to in the pre-marketing phase, it is not possible to control how these devices will behave when they are used on a daily basis or to predict possible injuries due to technical flaws, malfunctions, inaccuracies in the devices or even errors and gaps in their labeling and instructions for use [11].

\subsection{Relationship between Biotechnology and Medical Devices}

The specific goals of biotechnology are to stimulate the national production of implantable medical devices (cardioverters, pacemakers, endovascular prostheses, heart valves, etc.); to stimulate the creation of specific mechanisms to encourage innovation and the transfer of technology, particularly in areas of cell therapy, tissue engineering, protein and drug-loaded polymers and nanotechnology; and to stimulate the amplification of technology parks to produce products and services related to reconstructive surgery (breast implants) available to private and public health networks $[6,11]$.

The US Food and Drug Administration (FDA) has developed more than 200 new techniques for vaccines using biotechnology, including products for the treatment of cancer, diabetes, human immunodeficiency virus infection and acquired immune deficiency syndrome, as well as autoimmune disorders. These techniques, when associated with tissue culture procedures, can lead to professional specializations, generating jobs requiring higher qualifications [5].

Based on the above definitions, biotechnology can be briefly defined as an area of knowledge that studies ways of using living organisms to solve a problem or create a useful product for humankind. Conversely, medical devices are medical equipment and products made from metal, rubber, glass or fabrics [11-15].

Medical devices can be considered reusable or for single use. To safely reuse these materials, reprocessing is required, which includes cleaning and disinfection or sterilization of the device, along with quality control at all stages of its use, to ensure safety $[16,17]$.

Single-use or reusable items are made from plastics or elastomers, which are sensitive to heat, and are acquired by health institutions after being packaged and sterilized [18-22].

\subsection{Biocompatibility}

The biocompatibility of a medical device is the ability to self-react when directly or indirectly placed in contact with the human body [23-26]. Biocompatibility plays a key role and ensures that materials are safe to use in the human body and in endogenous fluids. Biocompatible materials are defined as those that do not induce an inflammatory response and must possess extreme immunogenicity or immunocytotoxicity to native cells, tissues or live organs [27, 28].

\subsection{Safety and Efficacy of Health Products}

Health products must be designed and manufactured in such a way that their use does not compromise the clinical condition or safety of patients, the safety and health of operators or, where applicable, of other people when used under appropriate conditions and for specific purposes. Benefits to patients should outweigh possible risks, which should be reduced to a level compatible with health safety and protection [9-11].

Health products must be manufactured in a way that guarantees their characteristics and perfor- 
mance. Therefore, special attention should be paid to the following: bility

a) Selection of the used materials, particular regarding their toxicity, and where applicable, flamma-

b) Compatibility of the used materials and compatibility between materials and biological tissues, cells and body fluids, according to the intended use of the medical device

Health products must be designed, manufactured and packaged in a way that minimizes the risk presented by contaminants and residues to people involved in their transport, storage, and use, as well as to patients, considering the intended purpose of the product. Special attention should be paid to exposed tissues and the duration and frequency of exposure $[15,18]$. Health products must be designed and manufactured in a way that the risks associated with derivative substances released from these products are reduced to a minimum [19].

\subsection{Regulation and Standardization of Health Products}

For any country, the guiding principles that encompass the regulation of medical items and biomaterials include the adoption of a manufacturing quality system and the application of technical standards for safety and efficacy based on a consistent approach through the use of internationally recognized technical standards and practices [29].

Standards are documents that represent a standardization of tests, methods, materials, items or procedures that have been widely validated both scientifically and technologically. Most regulatory bodies review and update their documents every five years [16].

International agencies, such as the American Society for Testing and Materials (ASTM), International Organization for Standardization (ISO), Organization for Economic Co-operation and Development (OECD) and the Brazilian Association for Technical Standards (ABNT) describe tests and trials, parameters, methodologies and conditions, and how data obtained with a test sample should be analyzed. Inter-laboratory validation of tests involves repetition of the method in various laboratories, which must agree with the degree of accuracy. Once standardized, this method may be used in any other laboratory, because the level of detail used is sufficient to ensure that different facilities obtain similar results for the same samples [16].

Both national and international standardization organizations exist. Regardless of their scope, they have representatives involved in the sector through the formation of technical committees that examine and organize the needs of each sector, developing and approving standard projects, which are later published. The final approval foresees the provisional design of standard projects among all interested parties, allowing for comments. After reading and reviewing the comments, the committee will draw up the final text, which will be approved, registered and published as a standard. Internationally, the main standardization agencies are the ISO and International Electrotechnical Commission. The implementation of international standards is not mandatory for member states of these organizations, contrary to the case of regional documents prepared by different nations [10,24].

Since the emergence of biomaterials in the market, the need for regulations to ensure their safety and efficacy has been evident. Safety data are obtained from tests that evaluate medical items and biomaterials according to biological, physicochemical and mechanical parameters. These tests follow the guidelines of regulatory agencies, such as the US FDA and ANVISA. These guidelines are set based on specific rules and standards of organizations and agencies such as the ISO, ASTM, US Pharmacopeia (USP) and other relevant pharmacopeia [24].

\subsection{Biological Evaluation of Biomaterials and Medical Devices}

Currently, most regulatory activities within the scope of biomaterials are associated with ISO 10993, which refers to the biological evaluation of medical devices, and with the considerations of Technical Committee 194, which refers to the group of organizations that participate in the elaboration and updating of the ISO. 
Standard "ISO 10993-1: General Principles" is the recommended starting point for biocompatibility evaluation, because it presents the fundamental principles that govern the biological evaluation of biomaterials and biomedical devices. In 1992, the ISO published a standard that harmonized previously published guidelines: Tripartite Agreement (Canada, England, and the USA), the ASTM, the British Standards Institute, and others [24].

ISO 10993 for "Biological Evaluation of Medical Devices" consists of several standards that are continually updated, revised, and expanded; it currently contains 20 parts that have been updated since 2010 . It includes guidelines from the characterization of each material or medical device to the appropriate selection of necessary tests and specific technical requirements for each biocompatibility test, as displayed in Table 1. Part 1 refers to the guidelines for selecting tests, part 2 addresses the requirements for animal well-being, and parts 3 to 20 mention guidelines for specific test procedures.

The implantation of any kind of material in the human body induces a typical response that depends on specific factors, such as the shape, size, geometry and surface characteristics and material properties. All these factors are related to various aspects of the recipient organism, such as age, immunological sensitivity, general health status and area of application or implantation.

The biocompatibility of a material takes into consideration all these interactions. For this purpose, several biological tests are described in ISO 10993. According to the standard, tests should be performed on materials or final products in conditions of use, and when there is any change in raw materials, processing, sterilization or clinical indication, the biomaterials need to be re-evaluated. For final products, the results of individual component tests are important, which should be performed because, in the event of any adverse effect, traceability becomes possible and the problem can be identified.

Biocompatibility evaluation is, therefore, one of the key tests required by regulatory agencies when submitting products for registration and quality control. The evaluation is performed through specific tests that are grouped based on animal models and in vitro techniques, which are complementary, to ensure a reliable result.

Table 1. Parts of Standard ISO 10993 (Biological Evaluation of Medical Devices) regarding Biocompatibility Tests.

BIOLOGICAL EVALUATION OF BIOMATERIALS

PART 1

PART 2

PART 3

PART 4

PART 5

PART 6

PART 10

PART 11

PART 12

PART 20
EVALUATION AND TESTS

ANIMAL WELL-BEING

GENOTOXICITY, CARCINOGENESIS, AND REPRODUCTIVE TOXICITY

HEMOCOMPATIBILITY

CYTOTOXICITY

IMPLANTS

IRRITATION AND SENSITIZATION

SYSTEMIC TOXICITY

PREPARATION OF SAMPLES

IMMUNOTOXICITY

Source: ISO 10993, 2009.

\subsection{Health Surveillance}

The Health Surveillance Agency acts on risk factors associated with products, materials, and services related to health, the environment, and the working environment. In recent decades, the dissemination of 
government actions and mechanisms designed to protect consumers' rights have resulted in increased efforts to ensure the quality and reliability of products [28].

The actions of the Health Surveillance Agency should promote and protect population health by intervening in health problems arising from the environment, the production and movement of goods or the provision of health services.

\subsection{Legislation}

In compliance with ISO 10993, an in vitro cytotoxicity assay is the first test to evaluate the biocompatibility of materials for medical use. In vitro methods have advantages over in vivo methods, since they reduce the number of animals needed for experimentation, yield important data easily, and in many cases, they take less time to be completed. Studies that use alternative in vitro methods with cell cultures to replace in vivo methods can be successfully completed because they are reproducible, faster, sensitive, and affordable [14].

An in vitro cytotoxicity assay using the agar diffusion method perfectly fits into the 3 R's rule, refinement, reduction, and replacement, of in vivo assays for in vitro assays using cell cultures.

The latter is quick to implement, displaying high reproducibility, low cost, high sensitivity and reproduces, as much as possible, physiological conditions similar to in vivo assays $[13,14]$.

Thus, sanitary surveillance should study possible toxic effects caused by health products to minimize and even prohibit their use, if they are proven to be cytotoxic.

Our goal herein was to evaluate which in vitro cytotoxicity assays are commonly used to evaluate medical devices as a warning regarding the greater reliability of these health products.

\section{METHODOLOGY}

The literature review was conducted in November 2016 through an online search of the following scientific electronic databases: PubMed, LILACS, and BIREME. The keyword searched for was biomaterials, and, because of the thousands of papers found, the search was refined using the following keywords, which were spelled either in English or Portuguese: biomaterial/biomaterials, biocompatibilidade/biocompatibility, citotoxicidade in vitrol in vitro cytotoxicity.

A total of 3366 papers resulted from the refined online search. Detailed analyses of these papers indicated that only 40 were related to the present study.

\section{RESULTS AND DISCUSSION}

The online search performed on all three databases resulted in a total of 3366 papers, of which 1006 (30\%) were related to the descriptor Biomaterial, while 1765 (52\%) were related to Biomaterials $\times$ Biocompatibility, $439(13 \%)$ to Biomaterials $\times$ in vitro Cytotoxicity, and 156 papers (5\%) to Biomaterials $\times$ Biocompatibility $\times$ in vitro Cytotoxicity [Table 2].

In recent years, biotechnology has been used in various economic sectors, particularly in the human

\section{Table 2. Database Search Results I.}

\begin{tabular}{ccc}
\hline DESCRIPTORS & PAPERS & PERCENTAGE \\
\hline Biomaterials & 1006 & $30 \%$ \\
Biomaterials $\times$ Biocompatibility & 1765 & $52 \%$ \\
Biomaterials $\times$ Cytotoxicity & 439 & $13 \%$ \\
Biomaterials $\times$ Biocompatibility $\times$ in vitro Cytotoxicity & 156 & $5 \%$ \\
TOTAL & 3366 & $100 \%$ \\
\hline
\end{tabular}


and animal health sectors, thereby increasing competitiveness among companies. Investments by industries in the field of biotechnology are huge, and several years of development and safety tests are needed before a product is ready for release in the market. An example is pharmaceuticals or other therapeutic application products, which require registration with the regulatory body, ANVISA in Brazil, thereby ensuring the rigorous evaluation of their safety level and biocompatibility.

Typically, the release of a health product for clinical use will depend on a rigorous preclinical evaluation performed through a series of laboratory tests. In the past, these tests almost always involved experimentation on laboratory animals. In vivo tests are still being widely discussed, mainly when they involve practical and ethical issues, in the search for alternative methodologies that precede or supersede in vivo tests.

In vitro tests, so-called because they involve cell cultures and tissues, are excellent technical alternatives. Some in vitro tests have already been validated by international standards for the evaluation of products for use in clinical practice. The choice and interpretation of the methodologies used are critical for analyzing the results and predicting the success or failure of a product. This may be why there are still controversial data in the literature. With this in mind, ISO 10993 offered a set of standards for evaluating the biocompatibility of a medical device, enabling warnings to consumers of risks related to new health products.

\subsection{Methods for In Vitro Cytotoxicity Analyses}

With increasingly rigorous controls regarding the use of laboratory animals, there is a need to develop and standardize in vitro tests that can detect the toxicity of medical devices for use in humans, mainly because they should not cause adverse effects to or harm patients [29-36].

Some in vitro methods are used to evaluate the toxicity of medical devices standardized by using cell cultures [37-40]. Methods involving cell cultures can be successfully employed because they are reproducible, fast, sensitive and easy to execute during an in vitro biocompatibility evaluation [41]. Nevertheless, due to the increased types of medical devices to be evaluated, there is a need to study new methodologies and choose among them those that can better detect the potential toxicities that these materials may display $[42,43]$.

According to ISO 10993, in vitro cytotoxicity assays were the first tests used to evaluate the biocompatibility of any material used in medical devices. After the material has been proven to be non-toxic in vitro, follow-up biocompatibility tests can be performed in laboratory animals, if necessary $[44,45]$.

\subsubsection{In Vitro Cytotoxicity Assay by the Agar Diffusion Method (Indirect Contact)}

The use of mammalian cell cultures in the biological evaluation of medical devices was first described in 1965, by Rosenbluth et al. [46]. Additional methods were published by Guess et al. the same year, and Northup, in 1986 [45], revised past and subsequent publications and emphasized the sensitivity and correlation between cell culture assays and biological reactivity in relation to in vivo biological reactivity assays for the biological evaluation of plastics. Since the $22^{\text {nd }}$ USP review, the agar diffusion test has been introduced as an in vitro biological reactivity assay to assess the safety of plastics for medical use $[15,47,48]$.

In the indirect contact assay, cells are grown as a monolayer in a 6-well culture dish and covered with a layer of agar [49]. The test sample is simultaneously placed on the top of the agar with neutral red dye and is incubated for $24 \mathrm{~h}$ at $37^{\circ} \mathrm{C}$ and $5 \% \mathrm{CO}_{2}$. Throughout this period, if chemicals from the test material are toxic, they diffuse through the agar and penetrate the cells, being deposited in cellular lysosomes. This causes the thin lysosomal membrane to break down and release the dye, forming a halo in the cell culture. The bigger the halo, the greater the diffusion of toxic chemicals released from the test material. The function of the agar layer is to protect cells from physical damage that could be caused by direct contact with the tested material and to facilitate the diffusion of chemicals released from samples containing polymers. The neutral red dye added to the cell culture is quickly taken up by viable cells stored in lysosomes. During necrosis, stained cells release the dye, resulting in areas containing decolorized, dead cells. 


\subsubsection{In Vitro Cytotoxicity Assay by the Direct Contact Method}

In compliance with the ISO standard method 10993-5, the in vitro cytotoxicity assay by the direct contact method was designed for plastics and chemicals, but was not suitable for high-density molecular materials, since these may cause physical cellular damage when in direct contact with cells. This methodology is similar to the agar diffusion test, although the samples to be tested can be chemical substances that will be placed on a filter paper, which will then be placed in direct contact with the cell culture, without the use of agar. The test sample comes into direct contact with the cellular monolayer, indicating the toxicity of the sample $[44,45]$.

\subsubsection{In Vitro Cytotoxicity Assay by the Elution Method}

In compliance with ISO 10993-5, the in vitro cytotoxicity assay by the elution method is suitable for evaluating extracts from polymeric materials. In this method, sample extractions at varying time intervals and at physiological and non-physiological temperatures can be evaluated. This method is also suitable for high-density materials and for establishing dose-response curves.

For use in this methodology, the sample should be prepared as described in the preparation of extracts using an injectable solution of sodium chloride $(0.9 \% \mathrm{NaCl})$ or serum-free culture medium according to the ratios described in ISO 10993-12 [45, 47].

\subsubsection{Neutral Red Assay}

The neutral red assay measures cell viability based on lysosomal activity. Only lysosomes in viable cells retain neutral red; therefore, it is possible to distinguish stained viable cells from decolored, damaged or dead cells. After diluting neutral red dye in an ethanol/acetic acid solution, lysosomal activity is measured at $540 \mathrm{~nm}$ in a spectrophotometer [48-51].

\subsubsection{MTT Assay}

The measurement of mitochondrial dehydrogenase activity, also known as the 3-bromide (4,5-dimethyl-2-thiazolyl)-2,5-diphenyl-2H-tetrazolium test (methyl thiazolyl tetrazolium, MTT), ensures the rapid evaluation of cell proliferation. This is a colorimetric assay for assessing cytotoxicity by measuring cell metabolism. Mitochondrial dehydrogenase present in the cytochrome $b$ and $c$ sites of living cells can cleave the tetrazole ring and the yellow water-soluble MTT formed is then reduced to form purple crystalline formazan. This substance is soluble in dimethyl sulfoxide (DMSO) and other organic solvents, but insoluble in water. The amount of crystals formed is positively correlated to the number of cells and their activity, and the measurement of the colorimetric value of the absorbance (optical density) reflects the number of surviving cells and metabolic activity [48].

\subsection{Validation and Test Results}

The validation of in vitro cytotoxicity assays for the agar diffusion, direct contact and elution methods is based on cell responses to treatments compared with negative and positive controls. The negative control, which is a non-toxic polypropylene plastic (USP), should show the absence of cytotoxicity (grade 0 ), whereas the positive control, a toxic plastic, should show a clear cytotoxic reaction ( $\geq$ grade 3 ).

The agar diffusion and direct contact methods provide a qualitative evaluation of in vitro cytotoxicity. The degrees of cytotoxicity of these methods are described in Table 3, taking into account the affected areas.

The degree of cytotoxicity of extracts in the elution assay is described in Table 4 and is based on the cellular morphological description. The sample is considered toxic if the values for the degrees of cytotoxicity displayed in Table 3 and Table 4 are greater than 2.

Qualitative tests consist of evaluating cellular morphology through descriptions, while quantitative tests quantify the number of cells and cellular activity after exposure to the tested material (ISO 10993-5).

For quantitative assessment, two tests are usually chosen to evaluate in vitro cytotoxicity: the neutral red and MTT assays. The cell viability test using neutral red was developed by Babich and Borenfreund in 
Table 3. Degrees of Cytotoxicity in the Agar Diffusion and Direct Contact Tests.

\begin{tabular}{ccl}
\hline Degree & CYTOTOXICITY & \multicolumn{1}{c}{ DESCRIPTION OF THE OF CYTOTOXICITY AREA } \\
\hline 0 & Absent & Absence of decolorization around or under the sample \\
1 & Slight & Decolorization limited to the area under the sample \\
2 & Mild & The size of the decolorized area from the sample is less than $0.45 \mathrm{~cm}$ \\
& Moderate & $\begin{array}{l}\text { The size of the decolorized area from the sample is between } 0.45 \mathrm{~cm} \\
\text { and } 1.0 \mathrm{~cm} \\
3\end{array}$ \\
& Severe & $\begin{array}{l}\text { The size of the decolorized area from the sample is greater than } 1.0 \\
\mathrm{~cm} \text {, but does not involve the entire plate }\end{array}$ \\
\hline
\end{tabular}

Table 4. Degrees of Cytotoxicity in the Elution Test.

\begin{tabular}{ccl}
\hline Degree & CYTOTOXICITY & \multicolumn{1}{c}{ CULTURE CONDITIONS } \\
\hline 0 & Absent & $\begin{array}{l}\text { Discontinuous cytoplasmic granules; without cell lysis } \\
\text { Up to 20\% of cells are vaguely round, without cytoplasmic granules; } \\
\text { lysed cells are occasionally present }\end{array}$ \\
1 & Slight & Mp to 50\% of cells are round, devoid of cytoplasmic granules, without \\
2 & Moderate & Up to 70\% of layers contain rounded or lysed cells \\
3 & Severe & Almost complete destruction of cellular layers \\
\hline
\end{tabular}

1990 [51] and is based on the uptake of neutral red, which is a weak cationic dye, by lysosomes in living cells. This is a colorimetric test that assesses the color intensity of neutral red incorporated into and later extracted from viable lysosomes, which is directly proportional to the number of viable cells. To measure cell viability, the following formula is used:

$$
\text { Viability }(\%)=100 \times \text { extract OD/control OD; }
$$

where extract $\mathrm{OD}$ is the average of optical densities of samples incubated with $100 \%$ of the extract and control OD is the average of the optical densities of samples incubated in the cell culture medium. Thus, for a test sample to be considered non-cytotoxic, it must present a value greater than $70 \%$ compared to the control. The cytotoxicity index $\left(\mathrm{CI}_{50}\right)$ is the concentration that kills $50 \%$ of cells in the assay and is determined based on the concentrations used in the dose-response curve.

The principle of the MTT assay is based on the mitochondrial dehydrogenase present in the cytochrome $b$ and $c$ sites of living cells that can cleave the tetrazole ring, and the yellow water-soluble MTT formed is reduced to form purple crystalline formazan. This substance is soluble in DMSO or other organic solvents, but it is insoluble in water.

The cytotoxicity test using agar diffusion is a qualitative assay that can be used for materials with different physical constitutions, including oily materials such as cosmetics, due to its feasibility and convenience [49]. However, although the neutral red assay is a quantitative test, which enables the calculation of the cytotoxicity index, the extraction of potential toxic elements or compounds is performed in an aqueous medium, which makes the analysis of certain materials difficult [48]. On the other hand, as stated by Sehnem [41], both qualitative and quantitative methods are equivalent and the choice of the most appropriate method must be made according to the type of analysis being conducted, i.e., qualitative when using the agar diffusion method or quantitative when performing the neutral red incorporation assay [41]. 
In general, cytotoxicity evaluation can be performed using qualitative or quantitative methods. Qualitative methods consist of evaluating cellular morphology through the description of scores, whereas quantitative methods are characterized by the quantification of the number of cells and their metabolic activity after exposure to the material being tested. The most appropriate method must be selected based on the type and intended use of the sample being evaluated and the availability of equipment in laboratories.

\section{FINAL COMMENTS}

Cytotoxicity tests are one of the most important indicators of an in vitro biological evaluation system. Furthermore, because of advances in cell biology, experimental methods to assess cytotoxicity are being continuously developed. An in vitro cytotoxicity evaluation of certain medical devices can show changes in cell morphology, proliferation and differentiation, as well as the interaction between cells and the material.

Cell cultures assays can be successfully performed because they are fast, reproducible, sensitive and affordable as in vitro biocompatibility studies. Moreover, they represent an important step in the development of new products by evaluating cytotoxic effects, thereby enabling formulations to be adapted where necessary. Thus, the new product development phase is optimized, in addition to the reduction in the number of animals required for the in vivo evaluation phase. Some previously OECD-validated in vivo tests for health products have replaced in vitro tests.

An important relationship is verified between cytotoxicity assays and the principle of the 3R's (reduction, refinement, and replacement) advocated by Russel and Burch.

\section{FUNDING}

This work did not receive any funding.

\section{REFERENCES}

1. Costa, E.A.M. (2014) Reflections on Health Safety in Reprocessing of Health Products. Health Surveillance in Debate, 2, 7-13. https://doi.org/10.3395/vd.v2i1.119

2. Vicente, M.G. (2012) Post-Marketing Surveillance of Health Products: Technovigilance as a Public Health Practice. Boletim Informativo de Tecnovigilância, 3.

3. Rai, R., Keshavarz, T., Roether, J.A., Boccaccini, A.R. and Roy, I. (2011) Medium Chain Length Polyhydroxyalkanoates, Promising New Biomedical Medical Devices for the Future, Medical Devices Science and Engineering: R. Reports, 72, 29-47.

4. Scelza, M.Z., Linhares, A.B., Da Silva, L.E., Granjeiro, J.M. and Alves, G.G. (2012) A Multiparametric Assay to Compare the Cytotoxicity of Endodontic Sealers with Primary Human Osteoblasts. International Endodontic Journal, 45, 12-18. https://doi.org/10.1111/j.1365-2591.2011.01941.x

5. Kumar, S. (2015) Biosafety and Biosecurity Issues in Biotechnology Research. Biosafety, 4, 153. https://doi.org/10.4172/2167-0331.1000e153

6. Biotechnology Development Policy. http://www.lexml.gov.br/urn/urn:lex:br:federal:decreto:2007-02-08;6041.

7. Reis, C., Landim, A.B. and Pieroni, J.P. (2011) Lessons from International Experience and Proposals for Incorporation of the Route Biotechnology in the Brazilian Pharmaceutical Industry. BNDES Setorial, 34, 5-44.

8. ANVISA (2010) National Health Surveillance Agency. Consumption and Health. Condoms: A Security Issue, ANVISA e DPDC. Ano, 3, No. 15.

9. ANVISA (2008) National Health Surveillance Agency. Resolution RDC No. 62 of September 3, 2008. Imprensa Nacional, Brasília. 
10. Trindade, E., Vicente, M.G., Santanna, P.C., Melchior, S.C., Pismel, A.M.C.L., Tinoco, A.T.M., Santos, M.M.A., Ferreira, P.A., Avila, R., Hofmeister, M.G.S., Sorgenfrei, R.H.H.H. (2010) Failure modes of medical-hospital articles: Biomedical Science and Engineering Analysis of Technical Complaints Involving Infusion Equipment Notified to ANVISA in 2007 and 2008. Boletim Informativo de Tecnovigilância, 2010, 1-20.

11. Infarmed (2013a) Obtido em 5 de setembro de 2015. de INFARMED. http://www.infarmed.pt/portal/page/portal/INFARMED/DISPOSITIVOS_MEDICOS

12. Alves, E.C. (2013) Clinical Investigation in Medical Devices. Portuguese Journal of Surgery, 24, 65-68.

13. Silva, R.B.T. (2013) Family Statute Resumes Disastrous Propositions. RIDB, 2, 13.

14. Vidal, M.N.P. and Miranda, A.C. (2010) Biomaterial Toxicity an Alert to Health Services. Analytica Magazine, São Paulo, 45.

15. Vidal, M.N., Aiub, C., Abrantes, S. and Zamith, H.P. (2009) Evaluation of Brazilian Medical Devices Using Agar Diffusion Cytotoxicity Assay. Revista Brasileira de Hematologia e Hemoterapia, 31, 84-87.

16. The United States Pharmacopeia (2017) National Formulary 34. 40th Edition, U.S. Pharmacopeial, Rockville. [87] Biological Reactivity Tests, in Vitro: Agar Diffusion Test. United States Pharmacopeial Convention.

17. Tironi, L.F. (2014) Globalization in Technological Services. Radar: Technology, Production and Foreign Trade, 33, 27-35.

18. Floriani, C.A. and Schramm, F.R. (2008) Palliative Care: Interfaces, Conflicts and Necessities. Science \& Collective Health, 13, 2123-2132. https://doi.org/10.1590/S1413-81232008000900017

19. Costa, D., Lacaz, F.A.D.C., Jackson Filho, J.M. and Vilela, R.A.G. (2013) Saúde do Trabalhador no SUS: Desafios para uma política pública [Occupational Health in SUS: Challenges to a Public Policy]. Revista Brasileira de Saúde Ocupacional.

20. Brasil, R.A. (2006) Resolução ANVISA RDC. nº 207 de 17 de novembro de 2006 Altera a Resolução ANVISA RDC [Resolution ANVISA RDC. No. 207 of November 17, 2006 Amends Resolution ANVISA RDC], 185.

21. Rocha, M. (2015) Vigilância de dispositivos médicos: Do registo à sua utilização [Surveillance of Medical Devices: From Registration to Use]. Tese de Doutorado.

22. Falk, M.L.R., Falk, J.W., de Oliveira, F.A. and da Motta, M.S. (2010) Acolhimento como dispositivo de humanização: Percepção do usuário e do trabalhador em saúde [Reception as Humanizing Device: Perception of the User and Health Worker]. Revista de APS, 13, 4-9.

23. Filho, S.A., da Silva, C.G.N. and Bigi, M.D.F.M.A. (2015) Bioprospecção e Biotecnologia [Bioprospecting and Biotechnology]. Parcerias Estratégicas, 19, 45-80.

24. International Organization for Standardization (1992) ISO 10993-5: International Standard Biological Evaluation of Medical Devices Part 5: Tests for Cytotoxicity in Vitro Methods.

25. da Silva, M.A., Guimarães, P.C.L., Pereira, T.D. and Honório-França, A.C. (2012) Biomateriais e sua biocompatibilidade numa abordagem multidisciplinar na área de saúde, alimentos funcionais e medicina regenerativa [Biomaterials and Their Biocompatibility in a Multidisciplinary Approach in Health, Functional Foods and Regenerative Medicine]. Revista Eletrônica Interdisciplinar, 2.

26. Borelli, V., Medeiros, F., Maia, M., Medeiros, R. and Higa, O.Z. (2014) Biocompatibilidade de biomateriais: Estudo exploratorio sobre a aplicacao da norma ISO 10.993 [Biotechnology of Biomaterials: An Exploratory Study on the Application of ISO 10993].

27. Motisuke, M., Rodas, A.C.D., Higa, O.Z., Carrodeguas, R.G. and Zavaglia, C.A.C. (2014) Avaliação de Citotoxicidade de Cimento de Fosfato de Cálcio [Evaluation of Cytotoxicity of Calcium Phosphate Cement].

28. Costa, E.A.M., Costa, E.A., Graziano, K.U. and Padoveze, M.C. (2011) Medical Device Reprocessing: A 
Regulatory Model Proposal for Brazilian Hospitals. Revista da Escola de Enfermagem da USP, 45, 1459-1465. https://doi.org/10.1590/S0080-62342011000600026

29. Reddy, L.H., Arias, J.L., Nicolas, J. and Couvreur, P. (2012) Magnetic Nanoparticles: Design and Characterization, Toxicity and Biocompatibility, Pharmaceutical and Biomedical Applications. Chemical Reviews, 112, 5818-5878. https://doi.org/10.1021/cr300068p

30. Sinn, S., Scheuermann, T., Deichelbohrer, S., Ziemer, G. and Wendel, H.P. (2011) A Novel in Vitro Model for Preclinical Testing of the Hemocompatibility of Intravascular Stents According to ISO 10993-4. Journal of Materials Science: Materials in Medicine, 22, 1521-1528. https://doi.org/10.1007/s10856-011-4335-2

31. He, Q. and Shi, J. (2011) Mesoporous Silica Nanoparticle Based Nano Drug Delivery Systems: Synthesis, Controlled Drug Release and Delivery, Pharmacokinetics and Biocompatibility. Journal of Materials Chemistry, 21, 5845-5855. https://doi.org/10.1039/c0jm03851b

32. Kunzmann, A., Andersson, B., Thurnherr, T., Krug, H., Scheynius, A. and Fadeel, B. (2011) Toxicology of Engineered Nanomedical Devices: Focus on Biocompatibility, Biodistribution and Biodegradation. Biochimica et Biophysica Acta, 1810, 361-373.

33. Uboldi, C., Giudetti, G., Broggi, F., Gilliland, D., Ponti, J. and Rossi, F. (2012) Amorphous Silica Nanoparticles Do Not Induce Cytotoxicity, Cell Transformation or Genotoxicity in Balb/3T3 Mouse Fibroblasts. Mutation Research, 745, 11-20.

34. Park, M.V., Neigh, A.M., Vermeulen, J.P., de la Fonteyne, L.J., Verharen, H.W., Briedé, J.J., van Loveren, H. and de Jong, W.H. (2011) The Effect of Particle Size on the Cytotoxicity, Inflammation, Developmental Toxicity and Genotoxicity of Silver Nanoparticles. Biomaterials, 32, 9810-9817.

35. Kido, H.W. (2011) Biocompatibilidade da vitrocêramica bioativa (Biosilicato): Análises in Vitro e in Vivo [Biocompatibility of Bioactive Vitreous (Biosilicate ${ }^{\circledR}$ ): in Vitro Analyzes in Vivo].

36. Ke, N., Wang, X., Xu, X. and Abassi, Y.A. (2011) The xCELLigence System for Real-Time and Label-Free Monitoring of Cell Viability. Methods in Molecular Biology, 740, 33-43.

https://doi.org/10.1007/978-1-61779-108-6 6

37. Zhou, H.M., Shen, Y., Wang, Z.J., Li, L., Zheng, Y.F., Häkkinen, L. and Haapasalo, M. (2013) In Vitro Cytotoxicity Evaluation of a Novel Root Repair Material. Journal of Endodontics, 39, 478-483.

38. Severino, P., Santana, M.H.A., Malmonge, S.M. and Souto, E.B. (2011) Polímeros usados como sistemas de transporte de princípios ativos. Polímeros, 21, 361-368. https://doi.org/10.1590/S0104-14282011005000061

39. Bauer, M., Lautenschlaeger, C., Kempe, K., Tauhardt, L., Schubert, U.S. and Fischer, D. (2012) Poly (2-ethyl-2-oxazoline) as Alternative for the Stealth Polymer Poly (ethylene glycol): Comparison of in Vitro Cytotoxicity and Hemocompatibility. Macromolecular Bioscience, 12, 986-998.

https://doi.org/10.1002/mabi.201200017

40. Bruinink, A. and Luginbuehl, R. (2011) Evaluation of Biocompatibility using in Vitro Methods: Interpretation and Limitations. In: Tissue Engineering III: Cell-Surface Interactions for Tissue Culture, Springer, Berlin, Heidelberg, 117-152. https://doi.org/10.1007/10 $2011 \quad 111$

41. Sehnem, D.P., de Souza, E.T.G., Benamor, L., de Jesus, L.D.S., de Menezes Valentim, R., Zambuzzi, W.F. and Takamori, E.R. (2012) Métodos alternativos para avaliação da citotoxicidade de biomateriais. Revista Rede de Cuidados em Saúde, 6.

42. De Oliveira Marreiro, R., Bandeira, M.F.C.L., de Almeida, M.D.C., Coelho, C.N., Venâncio, G.N. and de Oliveira Conde, N.C. (2015) Cytotoxicity Evaluation of a Mouthwash Containing Extract of Libidibia Ferrea. Brazilian Research in Pediatric Dentistry and Integrated Clinic, 14, 34-42.

43. Wang, J., Witte, F., Xi, T., Zheng, Y., Yang, K., Yang, Y., Zhao, D., Meng, J., Li, Y., Li, W., Chan, K. and Qin, L. 
(2015) Recommendation for Modifying Current Cytotoxicity Testing Standards for Biodegradable Magnesium-Based Materials. Acta Biomaterialia, 21, 237-249.

44. De Melo, W.M., Maximiano, W.M.A., Antunes, A.A., Beloti, M.M., Rosa, A.L. and de Oliveira, P.T. (2013) Cytotoxicity Testing of Methyl and Ethyl 2-Cyanoacrylate using Direct Contact Assay on Osteoblast Cell Cultures. Journal of Oral and Maxillofacial Surgery, 71, 35-41.

45. Northup, S.J. and Cammack, J.N. (1986) Mammalian Cell Culture Models. In: Handbook of Biomaterials Evaluation, Scientific, Technical, and Clinical Testing of Implant Materials, Macmillan, New York, 209-225.

46. Rosenbluth, S.A., Guess, W.L., Schmidt, B. and Autian, J. (1965) Agar Diffusion Method for Toxicity Screening of Plastics on Cultured Cell Monolayers. Journal of Pharmaceutical Sciences, 54, 1545-1547. https://doi.org/10.1002/jps.2600540139

47. Garcia, S.N., Gutierrez, L. and McNulty, A. (2013) Real-Time Cellular Analysis as a Novel Approach for in Vitro Cytotoxicity Testing of Medical Device Extracts. Journal of Biomedical Materials Research Part A, 101, 2097-2106. https://doi.org/10.1002/jbm.a.34507

48. Sastri, V.R. (2013) Plastics in Medical Devices: Properties, Requirements, and Applications. William Andrew.

49. Pithon, M.M. (2016) Citotoxicidade in Vitro de elásticos ortodônticos: Comparação entre duas metodologias [In vitro Cytotoxicity of Orthodontic Elastics: Comparison between Two Methodologies]. Saúde. Com. 4.

50. Kramer, D.B., Xu, S. and Kesselheim, A.S. (2012) Regulation of Medical Devices in the United States and European Union. The New England Journal of Medicine, 366, 848-855. https://doi.org/10.1056/NEJMhle1113918

51. Babich, H. and Borenfreund, E. (1990) Applications of the Neutral Red Cytotoxicity Assay to in Vitro Toxicology. Alternatives to Laboratory Animals: ATLA.

\section{Scientific Research Publishing}

\section{Submit or recommend next manuscript to SCIRP and we will provide best service for you:}

Accepting pre-submission inquiries through Email, Facebook, LinkedIn, Twitter, etc.

A wide selection of journals (inclusive of 9 subjects, more than 200 journals)

Providing 24-hour high-quality service

User-friendly online submission system

Fair and swift peer-review system

Efficient typesetting and proofreading procedure

Display of the result of downloads and visits, as well as the number of cited articles

Maximum dissemination of your research work

Submit your manuscript at: http://papersubmission.scirp.org/

Or contact jbise@scirp.org 